\title{
Analisa Strengths, Weaknesses, Opprotunities, and Threats (SWOT): Peluang dan tantangan Association of Southeast Asian Nations (ASEAN) dalam mewujudkan integrasi Asia Tenggara
}

\author{
Analyzing Strengths, Weaknesses, Opprotunities, and Threats (SWOT): \\ Chances and challenges of Association of Southeast Asian Nations \\ (ASEAN) in realizing Southeast Asia Integration
}

\author{
Lilik Salamah \\ Departemen Hubungan Internasional, Fakultas Ilmu Sosial Ilmu Politik, \\ Universitas Airlangga \\ Jalan Dharmawangsa Dalam, Surabaya 60286 \\ E-mail: salamahlilikumar@gmail.com
}

\begin{abstract}
As a regional organization, ASEAN has grown dynamically, proven by the increasing number of members and areas of cooperation that have been pursued. Along with globalization, this success is increasingly encouraging the will to achieve integration in ASEAN VISION 2020. Through SWOT analysis of strengths (Strengths), Weaknesses, Opportunities and Threats (SWOT) and with the base of regionalism theory, this paper examines the creation of perspective of Southeast Asian integration. Through the framework and analysis of the problems, the results show that there are potential of ASEAN states to grasp the available international opportunity. This is also supported by existing policies in flling opportunities in economic, socio-culture, or politic security area. However, various problems still occured in realizing ASEAN integration. The main problem generally related to the sense of belonging of a person with the value of unity in diversity. Given the circumstances that exist both internally and among ASEAN member countries, presumably the idealism of the formation of integrity of Southeast Asia region is difficult to be realized.
\end{abstract}

Keywords: ASEAN, regional integration, SWOT

\begin{abstract}
Abstrak
Sebagai organisasi regional, ASEAN telah berkembang secara dinamis terbukti dengan bertambahnya jumlah anggota maupun bidang kerjasama yang telah dilakukan. Seiring dengan globalisasi, keberhasilan ini makin mendorong kehendak untuk lebih terintegrasi sebagaiman tersurat dalam VISI ASEAN 2020. Melalui analisa SWOT yakni kekuatan(Strenghts), kelemahan (Weakensses), peluang (Opportunities) dan tantangan (Threats) (SWOT) dan berdasar teori regionalisme, artikel ini mengkaji bagaimana prespektif integrasi Asia Tenggara. Melalui kerangka pemikiran dan analisa kasus, hasil penelitian menunjukkan potensi kekuatan negara-negara di kawasan Asia Tenggara cukup besar untuk menangkap peluang internasionalisasi yang ada. Hal ini didukung dengan berbagai kebijakan untuk dalam mengisi peluang ekonomi, sosial budaya, maupun politik keamanan. Namun berbagai persoalan masih kerap muncul dalam mewujudkan integrasi ASEAN. Permasalahan dan tantangan utama adalah menumbuhkan kesadaran sense of belonging dengan nilai-nilai unity in diversity. Dengan berbagai persoalan yang ada baik secara internal maupun antar negara anggota ASEAN, kiranya idealisme terbentuknya integritas kawasan Asia Tenggara sulit terwujud.
\end{abstract}

Kata kunci: ASEAN, integrasi regional, SWOT

\section{Pendahuluan}

Secara umum negara-negara di Asia Tenggara pernah menjadi jajahan negara asing, terutama oleh kolonialisme Eropa. Penjajahan yang begitu lama berpengaruh besar pada dinamika negaranegara ini, tak terkecuali dalam perkembangannya sebagai organisasi regional. Ketika Perang Dunia II berakhir, realitas politik internasional diwarnai perang dingin antara dua superpower, Amerika Serikat dan Uni Soviet (sekarang Rusia) yang sangat konfliktual. Pola hubungan ini juga berpengaruh pada negara-negara Asia Afrika, tak terkecuali di Asia Tenggara. 
Menyadari akan rivalitas dua superpower, serta menyadari akan persamaan hak kedaulatan negara secara internasional, maka negara-negara Asia Afrika mengadakan Konferensi Asia Afrika 1955. Salah satu ini dari Deklarasi Bandung yang dicetuskan dalam konferensi adalah kehendak untuk bebas dari intervensi asing. Semangat konferenssi ini kemudian berproses menjadi Gerakan NonBlok (1961), di mana Indonesia dan Malaysia saat itu terlibat aktif sebagai anggota.

Pada tahun 1967 lima negara Asia Tenggara (Indonesia, Malaysia, Singapura, Filipina, dan Thailand) menandatangani Deklarasi Bangkok sebagai dasar pembentukan ASEAN (Assosiation of South East Asian Nations), untuk mengembangkan kesejahteraan bersama dan bebas dari intervensi asing. Secara internal, mereka bertekad untuk menyelesaikan persoalan-persoalan nasional maupun intra-regional dalam kerangka solidaritas kebersamaan dengan menjunjung tinggi kedaulatan masing-masing, dan secara eksternal asosiasi ini ditujukan untuk menjadi institusi yang bisa berperan aktif dalam kancah internasional.

Organisasi ini terus berkembang secara progresif dari semula hanya beranggotakan lima negara kemudian menjadi sepuluh negara, dimana posisi serta perannya juga sangat dinamis dalam perpolitikan internasional. Berbagai kebijakan dan kerja sama internasional bilateral maupun multilateral telah dilakukan. Misal, bidang politik telah dibentuk ASEAN Regional Forum (ARF) sebagai forum komunikasi persoalan politik dan keamanan dengan negara luar kawasan. Begitu juga bidang ekonomi, telah membentuk AFTA (ASEAN Free Trade Area) 1992, dan menggalang kerjasama ASEAN + 3 (Tiongkok, Jepang, Amerika Serikat) 1997 serta ACFT (ASEAN China Free Trade) tahun 2002.

Pada KTT ASEAN 2003 organisasi ini makin mengokohkan diri. Sepuluh negara anggota ASEAN sepakat mengganti Deklarasi Bangkok menjadi ASEAN Charter. Perubahan ini menjadi pijakan untuk memperkuat solidaritas dan kesatuan menuju ASEAN Community dalam wadah integritas kawasan Asia Tenggara. Suatu tekad untuk mewujudkan kesatuan ekonomi, politik dan budaya dalam satu bangunan integritas yang utuh.

Mengacu pada tujuan tersebut, penelitian ini mempertanyakan bagaimana peluang dan tantangan yang dihadapi dalam mewujudkan Integrasi Asia Tenggara? Pertanyaan ini patut diajukan berdasar pemikiran bahwa seiring dengan runtuhnya perang dingin dan arus globalisasi secara umum berdampak pada persoalan ekonomi, sosial dan politik internasional. Disamping itu, cita untuk mewujudkan integrasi Asia Tenggara melalui bangunan komunitas ASEAN melalui tiga pilar (politik, ekonomi, sosial budaya), nampaknya masih jauh dari realita. Banyak yang bersikap pesimis akan hal ini, sebagaimana dikatakan oleh Agatha Lee, kepala penjualan kawasan Asia Pasifik JP Morgan. "Integrasi ekonomi ASEAN ini target yang ambisius. Ini menjadi tantangan walaupun tak benar-benar mustahil" (Republika 2007).

Penelitian ini bertujuan untuk menganalisis kekuatan, peluang, kelemahan, dan tantangan (SWOT) yang dihadapi dalam mewujudkan integrasi ASEAN. Dengan analisis ini diharapkan memberi penjelasan tentang kondisi realita yang dihadapi, yang kemudian bisa dikalkulasi sebagai perspektif kebijakan kedepan.

Memahami perkembangan ASEAN semula memfokuskan pada kerjasama ekonomi, kemudian berkembang pada berbagai sektor dan berproses menuju kerjasama yang lebih luas dalam tiga bidang yaitu ekonomi, politik, dan sosial budaya. Keberhasilan ini merupakan salah satu alasan ASEAN untuk mewujudkan integrasi regional Asia Tenggara sebagaimana diamanatkan pada Visi 2020, namun mengacu pada kerangka pemikiran teori integrasi regional serta berdasar pada pendekatan politik, ekonomi dan sosial budaya serta analisis SWOT kiranya cita integrasi ini masih sulit diwujudkan. 


\section{Metode Penelitian}

Penelitian studi pustaka ini menggunakan metode deskriptif-analitis berbasiskan pada data-data kuantitaf maupun kualitatif dari berbagai tulisan dari beragam sumber pustaka yakni buku-buku, makalah ilmiah dalam bentuk jurnal, dan majalah serta situs online resmi.

Agar mendapatkan kajian yang komprehensif, penelitian ini menggunakan pendekatan politik, ekonomi, sosial budaya maupun aspek geografi secara integratif. Artinya, berbagai persoalan ini akan dianalisis secara utuh tidak terpisah-pisah dalam bingkai analisa SWOT, yaitu Strength (kekuatan), Weaknesses (kelemahan), Opportunities (peluang) dan Threats (hambatan). Analisis kekuatan dan kelemahan melihat beberapa aspek antara lain, luas dan potensi wilayah geografi Asia Tenggara serta jumlah penduduk beserta potensi dan relasi sosial di antara mereka. Sementara itu analisis peluang dan tantangan dikaitkan dengan relasi internasional antara ASEAN dengan dinamika politik dan ekonomi global.

\section{Dasar Pemikiran}

Ada tiga prespektif terbentuknya regionalisme internasional (Fawcett 2004: 429-466). Pertama, perspektif realis melihat bahwa regionalisme terbentuk karena negara-negara ingin memaksimalkan kepentingannya. Asumsi utamanya adalah negara selalu mementingkan tercapainya kepentingan nasional pada bidang apapun, sehingga regionalisme merupakan salah satu cara terbaik untuk mengakomodasi kepentingan nasional bersama dalam rangka untuk menghadapi aktor diluar wilayahnya (Rüland 2000:421-451). Perspektif kedua adalah liberalisme institusionalisme yang menekankan pada aspek ekonomi dan rasionalitas. Menurut kaum liberalis institusionalis, regionalisme terbentuk sebagai sebuah pelembagaan yang diperlukan karena negara-negara sadar akan pentingnya kerja sama. Kerja sama dilihat sebagai sebuah proses positif untuk menciptakan hubungan internasional yang harmonis, baik dari segi ekonomi maupun politik.

Ketiga, perspektif konstruktivisme menekankan pada faktor norma dan identitas bahwa regionalisme terbentuk karena keinginan menciptakan suatu identitas bersama atau collective identity. Perspektif ini didasari pemikiran fungsionalisme bahwa kerjasama fungsional antar negara dalam satu sektor akan melahirkan sektor lain yang memerlukan kerjasama lebih intens dimana bentuknya bisa berupa kerja sama transnasional ataupun kemudian menjadi makin solid berupa integrasi internasional. Beberapa sektor menuju integrasi internasional. a) Sektor ekonomi, ada sinergi dan kesatuan kebijakan dalam perekonomian regional. b) Sektor sosial, berusaha mentranformasi pilihan-pilihan nasional pada loyalitas komunitas politik yang lebih besar dengan mengembangkan sikap-sikap supranasional, misal tiap orang merasa dirinya sebagai bagian dari komunitas politik yang lebih besar yaitu sebagai bagian dari komunitas supranasional. c) Sektor politik. Pada sektor ini terjadi tranformasi kedaulatan negara atas kebijakan eksternal pada intitusi yang lebih tinggi. Pergeseran ini mungkin bisa berpengaruh pada kondisi dalam negeri negara, misal: kebijakan fiskal, pengaturan produksi bersama. d) Sektor keamanan. Integrasi bidang ini bisa berupa aliansi dimana negara yang kuat punya akses politik dominan dalam proses pengambilan keputusan, sementara negara kecil keamanannya dijamin.

Regionalisme tidak hanya disandarkan pada kesamaan geografis yang terdiri dari rangkaian pulau atau negara dalam suatu wilayah, melainkan sebagai sebuah kebijakan dari aktor negara untuk kemudian membentuk koordinasi dan kerjasama dengan negara lainnya dalam satu kawasan (Fawcett 2004: 429-466). Integrasi internasional adalah suatu proses dimana kondisi supranasional diciptakan sebagai unit politik yang lebih besar guna menyelenggarakan urusan yang dilakukan oleh pemerintah nasional.

Ernest B. Haas menyebut integrasi internasional merupakan suatu proses dimana aktor-aktor politik dari beberapa lingkungan nasional yang berbeda menggeser loyalitas, harapan, dan aktivitas-aktivitas politik pada institusi baru yang lebih besar dimana institusi tersebut melakukan yurisdiksi atas negaranegara nasional yang ada (Dougherty \& Pfaltzgraff 1971). Integrasi ditujukan untuk memaksimalkan potensi ekonomi, memaksimalkan potensi politik, meningkatkan solidaritas entitas, serta mengurangi dan 
menyelesaikan potensi konflik menuju satu kesatuan. Integrasi internasional tidak berjalan secara cepat melainkan perlahan melalui proses panjang yang tersusun, artinya proses itu bermula dari beberapa sektor kemudian berkembang dan makin meningkat menjadi satu kesatuan.

\section{Hasil dan Pembahasan}

Organisasi ASEAN lahir saat memanasnya perang dingin antara Liberalisme Amerika Serikat dan Komunisme Uni Soviet. Hampir semua negara dunia seakan terpecah dalam pengaruh dan kendali kedua superpower tersebut, tak terkecuali negara di Asia Tenggara. Misal, Thailand dan Filipina saat itu punya hubungan erat dengan Amerika Serikat. Sementara itu Uni Soviet juga punya pengaruh kuat di negara-negara Indochina maupun negara-negara lainnya. Kondisi ini menjadi salah satu alasan platform ekonomi dipilih sebagai dasar kerjasama ASEAN. Ada dua alasan mengapa platform ekonomi dipakai sebagai dasar kerjasama. Pertama, untuk menghindari sikap curiga antar negara dalam hal ideologi yang berkaitan dengan hubungan konfliktual Amerika - Uni Soviet. Kedua, masalah ekonomi adalah hal utama yang harus dikembangkan mengingat saat itu negara-negara anggota ASEAN adalah negara yang baru berkembang.

Dalam perjalanannya, walaupun ASEAN memformulasikan kerjasama ekonomi, tetapi persoalan politik di Asia Tenggara tetap menjadi perhatian. Misal, prinsip TAC (Treaty of Amity and Cooperations) untuk penyelesaian internal diantara mereka serta dicetuskan Deklarasi ZOPFAN (Zone of Peace Freedom and Neutrality ) 1971 untuk menangkal intervensi asing di kawasan Asia Tenggara. Ketika perseteruan politik di Indocina (Vietnam - Kamboja) tahun 1970an, ASEAN terlibat aktif untuk memertemukan pihak-pihak yang bertikai dalam Jakarta Informal Meeting. Mediasi di bawah pimpinan Indonesia ini akhirnya membuahkan hasil gemilang, yaitu negara Kamboja dan Vietnam saling berdamai. Tahun 1995 Vietnam masuk sebagai anggota ASEAN, kemudian disusul oleh Kamboja dan Republik Laos.

Sungguhpun permasalahan politik tak terabaikan, tetapi persoalan ekonomi tetap menjadi bidang prioritas bagi kerjasama ASEAN. Misal, pemberian preferensi perdagangan (preferential trade), ASEAN Industrial Projects Plan (1976), Preferential Trading Arrangement (1977), ASEAN Industrial Complementation scheme (1981), ASEAN Industrial Joint-Ventures scheme (1983), dan Enhanced Preferential Trading arrangement (1987) (ASEAN 2010).

\section{Menuju integrasi ASEAN}

Dari paparan diatas terlihat perkembangan kerjasama terutama bidang ekonomi sangat dinamis. Tetapi ketika terjadi krisis ekonomi Asia pada tahun 1998 ternyata banyak negara anggota ASEAN terpuruk. Bersamaan dengan ini terjadi pergeseran politik dan ekonomi secara global. Realita ini menjadi evaluasi bagi negara-negara Asia Tenggara untuk meningkatkan kerjasama yang lebih integratif.

Pada KTT ASEAN ke-9 tahun 2003, negara anggota ASEAN sepakat menetapkan visi bersama untuk kerjasama yang makin integratif sebagaimana ditandaskan dalam dokumen The ASEAN Vision 2020, menyebutkan

\footnotetext{
“....... adopted by the ASEAN Leaders on the 30th Anniversary of ASEAN, agreed on a shared vision of ASEAN as a concert of Southeast Asian nations, outward looking, living in peace, stability and prosperity, bonded together in partnership in dynamic development and in a community of caring societies." (ASEAN, 2010:60)
}

Kemudian pada KTT ASEAN ke-13 di Singapura, tanggal 20 November 2007 sepuluh negara anggota menetapkan ASEAN Charter. Pada KTT 2008 di Thailand, semua negara-negara ASEAN telah meratifikasinya. Perubahan dari Deklarasi pada Charter (Piagam) ini punya arti sangat penting. Deklarasi merupakan pernyataan kehendak sifatnya longgar, sedangkan Charter (Piagam) merupakan 
"Rules-based and peoples-oriented Organization" yakni secara hukum mempunyai kekuatan lebih mengikat, apalagi setelah diratifikasi berarti telah memasuki tahap pelaksanaan hukum positif (entry to force) dan punya kekuatan mengikat (binding force).

Hal menarik dari perubahan ini adalah secara politis ada kehendak kerjasama secara lebih utuh meuju integarsi masyarakat ASEAN, sebagaimana ditegaskan dalam (ASEAN Charter, Pasal 1, ayat 13) "to promote a people-oriented ASEAN in which all sectors or society are encouraged to participate in, and benefit from, the process of ASEAN integration and community building". Dalam cetak biru (blueprint) kesatuan yang utuh ini dilakukan dengan kerjasama yang lebih erat melalui tiga pilar yaitu pilar ekonomi, politik, dan sosial budaya menuju terbentuknya integrasi masyarakat Asia Tenggara (ASEAN Charter Pasal 1 ayat 2).

Tahun 2020 ditetapkan sebagai capaian integritas ASEAN dengan merajut sektor ekonomi, sosial budaya, dan politik keamanan sebagai kesatuan. Seiring dengan berbagai kerjasama regional, optimisme capaian ini makin menggelora, namun sampai tulisan ini dibuat ternyata target ini masih jauh dari kenyataan. Mengapa demikian? Untuk mengkajinya bisa dilihat dari analisis strength (kekuatan), weaknesses (kelemahan), opportunities (peluang) dan threats (hambatan).

\section{Analisa kekuatan (Strength)}

Posisi dan kekuatan suatu organisasi bisa dilihat dari power (kekuatan) yang dimiliki. Analisa kekuatan ini bisa dilihat dari beberapa aspek. a) Aspek institusi, secara kelembagaan keberadaan dan keberhasilan ASEAN sebagai organisasi internasional yang berbasis regionalisme telah diakui banyak negara, terbukti adanya aneka kerja sama yang dilakukan dengan berbagai negara baik secara bilateral maupun multilateral terutama dengan negara besar, seperti Amerika Serikat dan Tiongkok. b) Secara geopolitik, wilayah Asia Tenggara merupakan lintasan dunia yang punya arti strategis sangat penting. Wilayah Asia Tenggara kaya sumber alam dan energi secara strategis sangat penting bagi pelayaran dan pangkalan militer. Kolonialisme masa lalu dan imprialisme kapitalisme modern saat ini yang ingin mendominasi wilayah Asia Tenggara baik secara nasional maupun regional merupakan bukti akan potensi kekuatan dan keunggulan tersebut (Tarling 1999 ). c) Aspek sosial budaya. Nilai geoekonomi dan geopolitik diatas makin nyata bila ditinjau dari luas wilayah Asia Tenggara. Luas wilayah ini lebih dari $690.000 .000 \mathrm{~km} 2$ dengan perbandingan imbang antara darat dan laut, yaitu $325.357 .000 \mathrm{~km} 2$ wilayah darat dan $368.898 .000 \mathrm{~km} 2$ wilayah laut (Population Reference Bureu, 2015). Penduduk wilayah ini juga sangat besar, menurut data Lembaga Kependudukan Dunia, jumlah total penduduk wilayah Asia tenggara pada tahun tersebut adalah 626,6 juta jiwa dengan aneka ragam kekayaan budaya (Population Reference Bureu 2015).

Posisi dan potensi diatas merupakan nilai tawar tak terhingga dalam percaturan internasional, terutama dalam sektor ekonomi, apalagi bila dikaitkan total produk bruto negara-negara Asia Tenggara. Menurut Perdana Menteri Malaysia Datuk Seri Najib Razak, pada 2014 saja ASEAN sudah menjadi kekuatan ekonomi ketujuh terbesar dunia dengan total produk domestik bruto tahun 2013 mencapai 2,4 triliun dolar AS, kemudian tahun 2014 mencapai 2,5 triliun dolar AS (Republika 2007).

\section{Analisa kelemahan (Weakness)}

Meskipun Asia Tenggara punya nilai kekuatan dan nilai tawar cukup potensial sebagaimana diatas, namun sayang nilai hanya mengena pada tataran kuantitatif, sementara pada tataran kualitatif masih rendah dibanding negara lain. Menurut laporan The Global Technology Information Report 2012, indeks kesiapan jejaring teknologi negara-negara ASEAN adalah Singapura (2), Malaysia (29), Brunei ( 56), Thailand (77), Indonesia (80), Vietnam (83), Filipina (86), Kamboja (108). Indeks kesiapan ini tentu berkaitan dengan kemampuan infrastruktur, kemampuan ekonomi, dan kemampuan penguasaan teknologi. Artinya, secara umum indeks ini menggambarkan bahwa kemampuan negaranegara Asia Tenggara ( kecuali Singapura) akan kemampuan penggunaan teknologi informasi masih rendah dibanding negara yang sudah maju. Selain itu negara-negara Asia Tenggara baik secara 
nasional maupun regional masih menghadapi berbagai persoalan. Ancaman stabilitas nasional, sebagaimana yang ada di Filipina dan di Myanmar. Pemerintah Filipina sudah sejak lama belum bisa menyelesaikan masalah Moro, begitu juga Myanmar dengan masalah Rohingya.

Kasus Moro di kepulauan Mindanao-Filipina merupakan isu krusial sampai sekarang. Salah satu faktornya karena kebijakan kolonial yang diskriminatif saat itu. Setelah Filipina merdeka, mayoritas warga Islam Moro di pulau Mindanao merasa tersisihkan, mereka berjuang menuntut merdeka dengan membentuk Front Pembela Nasional Moro (MNLF- Moro National Liberation Frant) dan Front Pembela Islam Moro (MLIF-Moro Liberation for Islamic Front). Perjuangan ini dianggap sebagai pemberontakan oleh pemerintah sehingga menimbulkan konflik berkepanjangan sampai sekarang. Pada tahun 2009 diadakan perundingan oleh Komite Perdamaian Filipina Selatan (PCSP) dengan MILF. Perundingan ini menghasilkan keputusan bahwa Pemerintah Filipina menolak kemerdekaan, mereka diberi otonomi khusus namun hasil ini dianggap kurang memuaskan oleh Moro, sehingga konflik pecah kembali. Pembicaraan damai antara pemerintah dengan kelompok Moro telah berlangsung beberapa kali, tetapi belum ada kemajuan sampai sekarang.

Sementara itu Myanmar juga dilanda masalah sama. Dalam sejarah, ketika Ingris menguasai Burma 1824 -1942 Inggris mendatangkan orang-orang di wilayah jajahannya lainnya, dalam hal ini etnis Rohingya dari wilayah Banglades. Ketika Jepang menguasai Burma (1942- 1945) kelompok nasionalis pimpinan Aung San memusuhi etnis Rohyngya karena dianggap bagian dari kolonialisme Inggris. Tatkala Burma merdeka dan dalam proses stabilisasi, etnis ini tetap dianggap seperti itu sehingga terjadilah pemberontakan. Mereka tergabung dalam kelompok mujahid ini -- umumnya beragama Islam -- ini tidak diakui sebagai warga negara(Al Mahmood 2016). Sampai sekarang etnis ini tidak punya status warganegara. Pada bulan November 2016 perkampungan mereka dibakar sehingga banyak diantara mereka yang melarikan diri sebagai pengungsi ke beberapa negara wilayah Asia Tenggara.

Selain itu, beberapa masalah yang bisa mengganggu harmoni hubungan antar negara anggota ASEAN antara lain tentang perbatasan. Batas wilayah laut Indonesia di Laut Sulawesi khususnya Blok Ambalat masih menjadi persoalan antara Indonesia dan Malaysia, begitu juga Pulau Batu Putih di Selat Johor masih menjadi sengketa antara Malaysia-Singapura (Londo 2007). Kemudian masalah intra regional tentang Kepulauan Spratly yang disengketakan oleh sebagian negara anggoa ASEAN dengan negara di luar kawasan. Kepulauan Spratly di Laut China Selatan yang kaya akan sumber alam seperti minyak dan gas bumi ini diperebutkan oleh Tiongkok, Taiwan, dan beberapa negara di Asia Tenggara seperti Vietnam, Filipina, Malaysia, dan Brunei (Simamora 2013: 132). Berbagai upaya damai atas konflik ini sudah dilakukan tetapi belum terselesaikan. Pada tahun 2002 disepakati Declaration on the Code of Conduct of parties on the South China Sea yakni tiap negara yang terlibat sengketa diwajibkan untuk menyelesaikan permasalahan dengan cara damai, menjamin kebebasan bernavigasi dan penerbangan di wilayah yang menjadi sengketa, serta mereka harus bisa melakukan "pengendalian diri" atau self restraint, namun Code of Concuct ini sesungguhnya bersifat tidak mengikat karena tidak memiliki mekanisme penegakan, sehingga konflik di antara mereka sangat mungkin terjadi (Simamora 2013:136).

Masalah ketiga adalah masalah ekonomi, Negara-negara anggota ASEAN masih menghadapi disparitas cukup tinggi. Menurut JP Morgan, sebuah perusahaan perbankan multinasional dan jasa keuangan internasional, produk domestik bruto (PDB) di ASEAN pun tersebar tak merata. Singapura dan Brunei Darussalam, negara terkecil di kawasan ini, memiliki PDB per kapita lebih dari 40 ribu dolar AS, sementara negara-negara lainnya, seperti Myanmar dan Kamboja, hanya bisa menghasilkan PDB per kapita sebesar 1.000 dolar AS (Republika 2007).

\section{Analisa peluang}

Perubahan besar yang terjadi pada akhir abad dua puluh adalah kemenangan rezim ekonomi liberal atas ekonomi sosialisme komunis serta meningkatnya teknologi komunikasi dan arus globalisasi 
(McNamara 1989: 110-111). Globalisasi dan teknologi informasi mengakibatkan relasi internasional makin luas seakan tanpa batas. Realita ini menjadikan tiga peluang dalam hubungan internasional. Pertama dan yang utama adalah peluang ekonomi. Sistem ekonomi "tertutup" yang semula banyak dianut oleh rezim komunisme - terutama negara-negara di Eropa Timur -- kini bergeser pada ekonomi liberal. Artinya, negara-negara ini menjadi terbuka bagi perdagangan maupun investor. Bagi pemilik modal maupun negara industri tentu ini menjadi pasar yang sangat menggiurkan. Disamping itu kemajuan teknologi dan transportasi menjadikan efisiensi dalam produk maupun pemasaran. Teknologi juga membawa kemajuan inovasi produk makin beragam dan makin kompetitif. Disinilah peluangnya secara rasional, negara maupun kelompok negara bisa menjadi pemain handal bila menguasai pasar dan teknologi secara canggih.

Sebenarnya ASEAN telah menangkap peluang perubahan diatas dengan berbagai langkah strategis. Bidang ekonomi, pada KTT ke-5 ASEAN di Singapura tahun 1992 ASEAN bertekad untuk menjadi kawasan pasar terbesar ke-3 di dunia setelah Tiongkok dan India. Tekad ini sebagaimana digariskan AFTA (ASEAN Free Trade Area) dalam statetmennya "The main objectives of AFTA are to create a single market and an international production base, attract foreign direct investments and to expand intra-ASEAN trade and investment".

Kesepakatan ini kemudian dilakukan dengan Common Effective Preferential Tariff (CEPT) sebagai mekanisme utama yakni pengurangan dan eliminasi tarif, penghapusan hambatan-hambatan nontarif, dan perbaikan terhadap kebijakan-kebijakan fasilitasi perdagangan. Dalam perkembangannya, AFTA tidak hanya difokuskan pada liberalisasi perdagangan barang, tetapi juga perdagangan jasa dan investasi. Beberapa langkah implementasi yang telah dilakukan, antara lain pengurangan tarif sebagaimana ditetapkan ASEAN Framework Agreement on Services (AFAS) 1995, ASEAN Investment Area (AIA) dan ASEAN Framework Agreement on Services atau AFAS (ASEAN, 2010:60).

Disamping itu juga dilakukan kerja sama dengan negara luar kawasan, misalnya ASEAN-China Free Trade Area (ACFTA) tahun 1991. Pada 18 November 2011 bertepatan dengan KTT ASEAN XIV dilakukan Joint Statement of the 14th ASEAN-China Summit to Commemorate the 20th Anniversary of Dialogue Relations dimana mereka juga meresmikan ASEAN-China Centre sebagai pusat untuk mempromosikan kerja sama perdagangan, investasi, pendidikan dan pertukaran kebudayaan antara ASEAN-China. Dengan ini diharapkan ada peningkatan investor asing untuk menanamkan FDI di negara-negara Asia Tenggara, sekaligus diharap berbagai produk dalam negeri-termasuk produk agrikultural-dapat menembus pasar regional tanpa hambatan tarif yang berarti sehingga dapat memajukan perekonomian usaha kecil dan menengah (Hew \& Sen 2004) .

Kedua adalah peluang sosial budaya. Perubahan global juga memberi peluang bagus dalam kehidupan sosial budaya. Berkembangnya informasi dan transportasi yang makin canggih menjadikan relasi sosial makin mudah, makin cepat dan makin intens terutama dalam hal relasi sosial. Dengan pola seperti ini maka peluang kerja lintas sektoral dan lintas negara -kususnya antar negara Asia Tenggara- juga makin terbuka. Peluang bidang sosial budaya juga sangat menguntungkan bagi sektor wisata. Kemajuan teknologi makin mengenalkan kekayaan budaya pada pihak luar. Keragaman etnis, budaya, agama, dan bahasa pada tiap wilayah negara ASEAN merupakan kekayaan tak ternilai sebagai aset untuk menarik devisa wisatawan manca negara. Paket wisata yang terkordinasi sebagai "Wisata ASEAN" tentu punya nilai jual sangat tinggi karena koridor katulistiwa merupakan kehidupan sosial budaya yang unik, jarang dimiliki oleh negara lain.

Menghadapi hal ini ASEAN telah melakukan serangkaian kebijakan. Ada 6 area kunci strategis yang difokuskan dalam operasionalisasi sosial budaya (ASEAN 2013:2). Pertama, Human Development merupakan ranah program yang bertujuan untuk menciptakan kesetaraan di bidang edukasi, life-long learning, training capacity building, inovasi, wirausaha, dan bahasa Inggris. Kedua, Sosial Welfare and Protection berfokus dalam upaya menurunkan angka kemiskinan, menjamin kesejahteraan sosial, dan proteksi terhadap bencana dan penyakit menular berbahaya. Ketiga, Sosial Justice and Rights bergerak dalam bidang peningkatan pengaruh masyarakat terhadap pembuatan kebijakan atas hak 
asasi wanita, anak kecil, disable, lansia, dan pekerja migran. Keempat, Environmental Sustainbility berfokus dalam bidang proteksi sumber daya alam melalui manajemen pembangunan berkelanjutan dan konservasi tanah, air, mineral, energy. Kelima, Building ASEAN Identity yakni membangun nilai kebersamaan menuju satu kesatuan identitas bersama, identitas diri Asia Tenggara sebagai nilai bersama dan kesatuan kekuatan Unity in Diversity. Keenam, Narrowing the Development Gap yakni mempersempit jurang perbedaan (gap) diantara negara dan masyarakat Asia Tenggara, sehingga tumbuh kebersamaan secara menyeluruh.

Untuk mewujudkan tujuan tersebut dilakukan melalui serangkaian Plan of Actions ( $P$ of $A$ ), yaitu membangun komunitas kebersamaan yang sejahtera dan peduli akan lingkungan, serta terbentuknya harmoni dalam menjalankan kehidupan bernegara dan berbangsa regional Asia Tenggara. Beberapa program yang telah dilakukan dan bisa dirasakan, antara lain bebas visa antar negara ASEAN, pertukaran pelajar dan dosen, penelitian bersama, serta kolaborasi musik dan film. Berkaitan dengan peluang wisata, telah dilakukan promosi tahunan baik secara nasional maupun regional, misal Visit Indonesia Year, Visit ASEAN Year serta pemberian bebas visa bagi warga Asia Tenggara.

Sementara itu dalam rangka untuk saling melindungi peluang pekerja migran di Asia Tenggara, ASEAN menyatakan komitmennya atas perlindungan hak-hak tenaga kerja migrant workers sebagaimana diadopsi dalam the ASEAN Declaration on the Protection and Promotion of the Rights of Migrant Workers juga menetapkan Mutual Recognition Agreements (MRA) 1995 dimana salah satu ketentuannya adalah memungkinkan adanya sertifikasi kepada para tenaga ahli yang ingin bekerja di negara Asia Tenggara. Ketiga adalah peluang politik keamanan. Kemajuan teknologi menjadikan jaringan kejahatan makin mudah menyebar dan menyusup ke berbagai negara. Di samping itu masalah keamanan sosial misal masalah lingkungan, keamanan pangan, kesehatan dan kemanusiaan juga menjadi ancaman serius. Dalam rangka untuk menghadapi persoalan politik keamanan tersebut dibentuklah ASEAN Regional Forum (ASEAN, 2009:9), suatu forum multilateral untuk membahas berbagai isu keamanan internasional khususnya di wilayah Asia Tenggara. Forum ini bertujuan mengadakan dialog konstruktif dalam bidang politik keamanan dengan mengupayakan pelembagaan konsep Confidence Building Measures (CBMs), Preventive Diplomacy dan Conflict Resolution (Deplu.go.id. 2008). Menurut Acharya, forum ini sangat penting karena didalamnya melibatkan pemain dominan dalam sistem internasional, seperti Amerika Serikat, Rusia, Jepang, Tiongkok, dan Uni Eropa (Acharya, 2011:173).

Melalui forum ini masalah keamanan bisa diupayakan penyelesaian bersama. Realisasinya antara lain, Defence Officials' Dialogue dan ASEAN Security Policy Conference (ASPC) juga diadakan pertemuan tahunan ASEAN Defence Ministers Meeting (ADMM) dan ASEAN Defence Senior Officials' Meetings (ADSOM). Serangkaian pertemuan rutin ini merupakan dasar langkah pertahanan keamanan bersama. Dengan kerja sama ini diharap akan tercipta kesatuan politik dan keamanan masyarakat menuju ASEAN Political and Security Community (APSC).

\section{Analisa tantangan}

Dariuraian diatas terlihat bahwaASEAN telah berupaya mengisi berbagai peluang kerjasama dalam kerangka untuk mewujudkan integrasi kawasan. Upaya ini berpacu dengan kemajuan teknologi dan globalisasi yang makin masif. Artinya, capaian program ekonomi yang dilakukan oleh ASEAN seakan berkembang seperti deret hitung, sementara perkembangan industri dan teknologi negara lain banyak yang berkembang seperti deret ukur, misalnya Tiongkok. Dalam persaingan ekonomi seperti ini, suka atau tidak suka negara atau institusi regional akan dihadapkan pada posisi sebagai subyek yang berperan dan mewarnai persaingan itu, atau sebagai obyek dari persaingan tersebut. Sementara itu dalam bidang sosial budaya, kemajuan teknologi dan arus globalisasi juga berpacu dengan nilai-nilai solidaritas dan identitas nasional.

Dalam kerangka integrasi regional, nilai-nilai ini tentu dibangun dalam kerangka identitas kebersamaan regionalisme, artinya rasa kebersamaan dan identitas regional merupakan identitas bersama. Integrasi regional akan kuat manakala anggota dari organisasi itu merasa ada manfaat bersama baik untuk kepentingannya sendiri dan kepentingan bersama ada keselarasan sehingga 
merasa integrasi itu penting bagi kebersamaan. Idealisme ini bisa dicapai apabila masing-masing negara anggota meletakkan kepentingannya tidak lebih tinggi dari kepentingan kelompok. Integrasi ini akan terwujud bila negara-negara sadar akan pentingnya kerja sama dengan hubungan positif untuk menciptakan hubungan internasional yang harmonis, baik dari segi ekonomi maupun politik. Misal, ASEAN telah menetapkan Mutual Recognition Agreements (MRA) 1995 tentang perlunya sertifikasi kepada para tenaga ahli yang ingin bekerja di negara Asia Tenggara, namun kesepakatan ini tidak dibarengi dengan regulasi yang ketat baik secara institusional ASEAN maupun negara masingmasing, sehingga MRA ditujukan memperketat mobilitas tenaga kerja yang akhirnya memunculkan berbagai kasus tenaga kerja ilegal yang sangat potensial terjadinya kejahatan kemanusiaan dan mengganggu stabilitas dan integritas nasional maupun regional (Hoag 2013:34-42).

Integrasi internasional merupakan suatu proses dimana aktor-aktor politik dari beberapa lingkungan nasional yang berbeda menggeser loyalitas, harapan, dan aktivitas- aktivitas politik pada institusi baru yang lebih besar dimana institusi tersebut bekerja untuk kepentingan regional (Dougherty \& Pfaltzgraff 1971). Sebagaimana diajukan oleh teori regionalis prespektif konstruktivisme bahwa integrasi menekankan pada norma dan identitas kolektif. Supaya integritas Asia Tenggara tercipta, perlu dikembangkan solidaritas dan persatuan antar bangsa dengan mementingkan kepentingan rakyat dan membangun identitas bersama menciptakan one identity harus ada asimilasi sosial dan identitas sosial bersama (Narine 2002), yaitu kebersamaan nilai, identitas, dan kebanggaan sebagai satu bangsa yaitu bangsa Asia Tenggara, namun ini tidak mudah karena butuh pergeseran nilai-nilai supra state yang tentunya selaras dengan nilai-nilai nasional, butuh asimilasi sosial regional dan butuh value sharing di antara relasi sosial tidak hanya antara supra struktur melainkan keseluruhan masyarakat Asia Tenggara (Narine 2002) .

Di sini permasalahan dan tantangannya bagaimana menumbuhkan kesadaran akan sense of belonging dengan nilai-nilai unity in diversity. Perlu kerja sama menyeluruh baik negara maupun aktor nonnegara yang berproses dengan didasari norma-norma tertentu. Menurut Ayyob, hal ini tidak mudah karena negara-negara kawasan Asia Tenggara punya berbagai persoalan yang belum terselesaikan di antara mereka, misal masalah perbatasan atau faktor sejarah yang traumatik di antara mereka (Ayyob 1986).

\section{Simpulan}

Organisasi ASEAN dibentuk saat perang dingin yang diwarnai persaingan ideologi dua superpower. Organisasi ini semula mendasarkan pada kerja sama ekonomi, namun seiring dengan perkembangan politik saat itu, maka kiprah politik dan keamanan tidak bisa diabaikan. Seiring dengan berakhirnya perang dingin dan teknologi informasi komunikasi global yang makin meningkat, ASEAN yang makin berkembang ini bertekad mewujudkan integrasi regional dalam bangunan ASEAN Community dari tiga pilar yakni keamanan, ekonomi, dan sosial budaya.

Melalui kerangka pemikiran teori integrasi regional dan analisis SWOT ditemukan fakta bahwa potensi kekuatan negara-negara di kawasan Asia Tenggara yang cukup besar dan berupaya menangkap peluang internasional yang ada. Berbagai kebijakan telah dilakukan dalam mengisi peluang ekonomi, sosial budaya maupun politik keamanan. Mengkaji berbagai kelemahan, peluang dan tantangan yang ada, cita untuk terwujudnya integrasi masyarakat Asia Tenggara secara utuh sebagaimana slogan 'One Vision, One Identity, One Community' yang tertuang dalam ASEAN Vision 2020 kiranya sulit tercapai. Idealisme ini tidak semudah membalik tangan dan tentu butuh waktu lama melalui proses sosialisasi dan penjiwaan dan komitmen bersama.

Agar idealisme ini perlu dilaksanakan beberapa langkah, sebagai berikut: a) Meningkatkan pemahaman masyarakat tentang manfaat hubungan serta kerjasama dan kebersamaan integritas Asia Tenggara. b) Meningkatkan koordinasi antar pemerintah dengan ASEAN beserta instansi-instansi terkait dan berbagai komponen masyarakat, dalam segala bidang khususnya pada bidang sosialbudaya sebagai elemen dasar dari bangunan integritas. c) Menyelesaiakan persoalan internal maupun 
regional secara bersama untuk terciptanya stabilitas nasional maupun kawasan. d) Meningkatkan diplomasi preventif dengan melibatkan supra struktur maupun infra struktur baik pada skala nasional, regional, maupun internasional, sehingga tercipta kebersamaan dalam mewujudkan integritas dan perdamaian secara keseluruhan.

\section{Daftar Pustaka}

About Us (2015) [Diakses 19 Juni 2015]. http://aseanregionalforum.asean.org/about.html.

Acharya A (1997) Ideas, identity, and institution-building: From the 'ASEAN Way to the Asia-Pacific Way?'. The Pacific Review 10 (3):319-346.

Al-Mahmood SZ (2016) Timeline: A Short History of Myanmar's Rohingya Minority. [Diakses 25 Desember 2016]. https://blogs.wsj.com/indiarealtime/2016/12/23/timeline-a-short-historyof-myanmars-rohingya-minority/.

ASEAN Political-Security Community Blueprint (2009) Jakarta: ASEAN Secretariat.

ASEAN Political-Security Community (2015) [Diakses 19 Juni 2015]. http://www.asean.org/ communities/asean-political-security-community.

ASEAN Regional Forum (ARF) (2015) [Diakses 9 Juni 2015]. http://www.asean.org/communities/ asean-political-security-community/category/asean-regional-forum.

Ayoob M (1986) Regional Security and the Third World. London: Croom Helm.

Dougherty JR \& Pfaltzgraff. Jr. L (1971), Contending Theories of International Relations. J.B. Lippincot Company: Philadelphia.

Fawcett L (2004) Exploring regional domains: A comparative history of regionalism. International Affairs 80 (3):429-446.

Hew D \& Sen R (2004) Towards An ASEAN economic community: Challenges and prospects, ISEAS Working Papers. Economics and Finance.

Narine S (2002) Explaining ASEAN: Regionalism in Southeast Asia. London: Lynne Reinner Publisher, Inc.

Republika (2007) Mimpi Integrasi ASEAN.

Tarling N (1999) The Cambridge of Southeast Asia Vol. Three, From 1800 to the 1930. Cambridge: Cambridge University Press. 